\title{
Pesticide Residues of MEP, MPP and PAP in Mulberry Stumps and Its Effect on the Silkworm (Bombyx mori, L.)
}

\author{
Hirosi Sugiyama and Takashi Emori \\ Sericultural Experiment Station, Yatabe, Tsukuba, Ibaraki 305, Japan
}

(Received December 24, 1979)

\begin{abstract}
Residual levels of pesticides, MEP, MPP and PAP, in parts of mulberry stumps were determined by means of $g l c$. Ten days after application, a high concentration of all chemicals remained in the bark: MEP 66-790 ppm, MPP 52-120 ppm and PAP 58-347 ppm. Several ppm of these pesticides also remained in the wood. Only a small quantity, 0.14-1.08 ppm of MEP remained in the pith. Silkworms can be reared normally on mulberry leaves harvested from the pesticide-treated stumps, but a slightly reduced cocoon weight was noted case of MEP and MPP-treatment.
\end{abstract}

\section{INTRODUCTION}

In the field of sericulture, the use of MEP, MPP and PAP formulations for the protection of mulberry trees against damage by the yellow-spotted longicorn beetle (Psacothea hilaris PASCOE) has increased. The application of these pesticides is usually restricted to a short period immediately after the summer pruning of the mulberry tree, since experience has shown that the silkworm has been damaged when the mulberry leaves retain the contaminated residue of those pesticides. Larvae of the beetle which is most sensitive to these pesticides develop in September and/or October in the Kanto area. ${ }^{1,2)}$ Rearing of the silkworm is also carried out during this period by providing mulberry leaves. Therefore, it is essential to know the extent to which the pesticide residue remains on mulberry leaves after application. In this paper, we wish to report on the pesticide residue found in parts of a mulberry stump and the quality of the cocoons resulting from silkworms reared on mulberry leaves harvested from the pesticidetreated stump.

\section{MATERIALS AND METHODS}

\section{Mulberry Tree}

A "Takanegari" (semi-low cut training) of the Rosō strain, ten years old, was used for this study during the spring rearing season.

\section{Silkworm}

The fifth instar larvae of a hybrid from Nichi 134 and Shi 135 were used. The silkworm was reared on the leaves of the pesticide-treated mulberry stump.

\section{Pesticides}

MEP (O,O-dimethyl O-(3-methyl-4-nitrophenyl)thiophosphate, $50 \%$ emulsion) and MPP (O,O-dimethyl $O$-(3-methyl-4-methylthiophenyl)thiophosphate, $50 \%$ emulsion) with $\mathrm{EDB}$ (1,2-dibromoethane) added to $10 \%$ were diluted to $1 / 50,1 / 100$ and $1 / 200$; each $200 \mathrm{ml}$ was then sprayed on the mulberry tree. PAP (ethylacetate of O,O-dimethyldithiophosphorylphenyl, 10\% emulsion) with EDB added to $10 \%$ was diluted to $1 / 10,1 / 20$ and $1 / 40$, and each $200 \mathrm{ml}$ of the diluted formulation was used for the test.

\section{Analysis of Pesticide Residues}

The bark, wood and pith of the pesticide- 
treated mulberry stump (circumference, about $20 \mathrm{~cm}$ ) were separated carefully at a definite day after the application of the pesticide. Ten $g$ of the chipped samples were dipped in $100 \mathrm{ml}$ of acetonitrile for a day and extracted twice with $50 \mathrm{ml}$ of $n$-hexane. The hexane extract was concentrated and was subjected to chromatography on an alumina column containing water to $10 \%$, and eluted with acetone. A certain volume of the concentrated acetone eluate was applied to gas liquid chromatography. The condition of glc was as follows: apparatus, Hewlett Packard 5710A; detector, N-P FID; column, 2\% OV-101 chromosorb W, HP, 100/120 mesh, $1.2 \mathrm{~m}$; detector temp., $300^{\circ} \mathrm{C}$; column temp., $190^{\circ} \mathrm{C}$; injection port temp., $250^{\circ} \mathrm{C} ; \mathrm{N}_{2}, 30 \mathrm{ml} / \mathrm{min}$; air, $50 \mathrm{ml} / \mathrm{min} ; \mathrm{H}_{2}, 3 \mathrm{ml} / \mathrm{min}$. The retention time of MEP, MPP and PAP was 3.3, 4.2 and $5.5 \mathrm{~min}$, respectively. Quantitative assay of MEP and MPP was performed employing $\mathrm{PAP}$ as an internal standard. The standard curve of each pesticide was drawn with the height of peak.

\section{Silkworm Rearing}

Twenty female larvae of the fifth instar were reared from newly ecdysis to maturation on fresh mulberry leaves harvested from the mulberry stump which had been treated with pesticides. Cocoons were weighed on the seventh day after maturation of the larvae.

\section{RESULTS AND DISCUSSION}

Ten days after the application of the pesticides, a high concentration of MEP, MPP and PAP, remained in the bark of the mulberry stump (Table 1). The amount of pesticide residue was less in proportion to the magnification of the dilution applied. No residue was detected in pith in any case of MPP spraying. Residues of PAP were negligible in cases when 20 and 40 times dilutions were used. Moreover, the mulberry leaves of the treated stumps contained no detectable residues.

Silkworms can be reared on mulberry leaves of pesticide-treated stumps without any damage (Table 2). The larvae did not show any typical toxic symptoms. There were a few dead larvae due to flacherie, but not in any case because of the pesticidal effect of the
Table 1 Pesticide residues in parts of a stump 10 days after application of chemicals.

(ppm)

\begin{tabular}{crrlr}
\hline $\begin{array}{c}\text { Pesti- } \\
\text { cide }\end{array}$ & $\begin{array}{c}\text { Dilu- } \\
\text { tion }\end{array}$ & Bark & Wood & Pith \\
\hline & 50 & 791.8 & 9.75 & 1.08 \\
MEP & 100 & 305.0 & 2.03 & 0.37 \\
& 200 & 66.5 & 0.62 & 0.14 \\
& 50 & 120.2 & 1.32 & ND \\
MPP & 100 & 52.6 & 1.56 & ND \\
& 200 & 73.8 & 0.33 & ND \\
PAP & 10 & 347.7 & 5.9 & 0.58 \\
& 20 & 61.2 & 0.002 & ND \\
& 40 & 58.6 & 0.55 & ND \\
\hline
\end{tabular}

Rainfall totalled $153 \mathrm{~mm}$ during this period.

The formulation of MEP and MPP used in the experiments was $50 \%$ emulsion and that of PAP was $10 \%$ emulsion.

Amount of pesticide residue (ppm) was indicated by an average value of two samples per series.

Table 2 Cocoons of silkworms reared on mulberry leaves of the pesticide-treated stump.

\begin{tabular}{|c|c|c|c|c|c|}
\hline \multirow[b]{2}{*}{$\begin{array}{l}\text { Pesti- } \\
\text { cide }\end{array}$} & \multirow[b]{2}{*}{$\begin{array}{l}\text { Dilu- } \\
\text { tion }\end{array}$} & \multicolumn{4}{|c|}{ Number of cocoons } \\
\hline & & $\begin{array}{l}\text { Normal } \\
\text { cocoon }\end{array}$ & $\begin{array}{l}\text { Double } \\
\text { cocoon }\end{array}$ & $\begin{array}{l}\text { Dead } \\
\text { worm } \\
\text { cocoon }\end{array}$ & $\begin{array}{l}\text { Larvae } \\
\text { dead by } \\
\text { flacherie }\end{array}$ \\
\hline MEP & $\begin{array}{r}50 \\
100 \\
200\end{array}$ & $\begin{array}{l}16 \\
17 \\
16\end{array}$ & & $\begin{array}{l}1 \\
2\end{array}$ & $\begin{array}{l}3 \\
3 \\
2\end{array}$ \\
\hline MPP & $\begin{array}{r}50 \\
100 \\
200\end{array}$ & $\begin{array}{l}15 \\
16 \\
14\end{array}$ & 1 & $\begin{array}{l}2 \\
1 \\
3\end{array}$ & $\begin{array}{l}3 \\
3 \\
1\end{array}$ \\
\hline PAP & $\begin{array}{l}10 \\
20 \\
40\end{array}$ & $\begin{array}{l}13 \\
17 \\
17\end{array}$ & 2 & $\begin{array}{l}1 \\
1\end{array}$ & $\begin{array}{l}3 \\
2 \\
2\end{array}$ \\
\hline Contr & & 16 & & & 4 \\
\hline
\end{tabular}

residues. So-called cocoon qualities, i.e., cocoon weight, cocoon shell weight and percentage of shell weight, are presented in Table 3. Cocoon weight and cocoon shell weight proved to be less in those silkworms reared on mulberry leaves of the MEP-treated stump compared with the untreated stump. A significant difference in cocoon weight was noticed between silkworms reared on the MEP or MPP treated leaves and those reared on the control leaves. As mentioned above, pesticide residues on mulberry leaves were not detected. Satō et al. ${ }^{3,4)}$ have proposed safety levels for MEP and PAP of less than 0.02 ppm, and for MPP of less than $0.5 \mathrm{ppm}^{5}{ }^{5}$ 
Table 3 Cocoon quality of the silkworms reared on mulberry leaves of the pesticide-treated stump.

\begin{tabular}{cclccc}
\hline $\begin{array}{c}\text { Pesti- } \\
\text { cide }\end{array}$ & $\begin{array}{c}\text { Dilu- } \\
\text { tion }\end{array}$ & $\begin{array}{c}\text { Cocoon weight } \\
(\mathrm{g})\end{array}$ & $\begin{array}{c}\text { Cocoon shell } \\
\text { weight }(\mathrm{cg})\end{array}$ & $\begin{array}{c}\text { Percentage of } \\
\text { shell weight }(\%)\end{array}$ & $\begin{array}{c}\text { Number of } \\
\text { cocoons }\end{array}$ \\
\hline \multirow{3}{*}{ MEP } & 50 & $2.030 \pm 0.102^{* *}$ & $46.87 \pm 4.59$ & $23.14 \pm 1.85$ & 16 \\
& 100 & $2.186 \pm 0.124^{*}$ & $49.67 \pm 5.02$ & $22.75 \pm 2.17$ & 17 \\
& 200 & $2.219 \pm 0.116^{*}$ & $49.59 \pm 2.18$ & $22.35 \pm 0.81$ & 16 \\
MPP & 50 & $2.213 \pm 0.297 * *$ & $51.10 \pm 5.55$ & $23.08 \pm 2.01$ & 15 \\
& 100 & $2.152 \pm 0.127 *$ & $49.12 \pm 3.76$ & $22.79 \pm 0.70$ & 16 \\
PAP & 10 & $2.178 \pm 0.237$ & $53.05 \pm 4.54$ & $24.45 \pm 1.79$ & 14 \\
& 20 & $2.371 \pm 0.189$ & $55.46 \pm 2.81$ & $23.48 \pm 1.83$ & 13 \\
Control & 40 & $2.445 \pm 0.147$ & $57.97 \pm 4.46$ & $23.67 \pm 0.98$ & 17 \\
\hline
\end{tabular}

The silkworms were reared on mulberry leaves harvested from stumps 20 days after application of pesticides.

** Significant difference p 0.01, * Significant difference p 0.05 .

Double cocoon was eliminated from the calculation and f-test.

The cause of the deterioration of quality of cocoons from silkworms reared on mulberry leaves of the MEP- and MPP-treated stumps is not clear at the present time.

\section{ACKNOWLEDGEMENT}

We thank Drs. H. Shigematsu and M. Kobayashi for their valuable suggestions and kind reading of the manuscript.

\section{REFERENCES}

1) G. Ishii, T. Emori \& Y. Toida: Sansi-Kenkyu, 46, 39 (1963)

2) G. Ishii, T. Emori \& Y. Toida: Sansi-Kenkyu 52, 28 (1964)

3) Y. Satō, Y. Naono \& H. Sugiyama: SansiKenkyu 99, 41 (1976)

4) Y. Satō, Y. Naono \& H. Sugiyama: SansiKenkyu 98, 39 (1976)

5) Y. Satō, T. Emori \& H. Sugiyama: J. Sericult. Sci. Jpn. 46, 493 (1977)
要 約

\section{桑株中の MEP, MPP および PAP の残留とカ イコに及ぼす影響}

杉山 浩, 江森 京

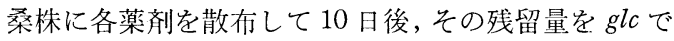
測定した。樹皮中に拈いては各農薬は高濃度に残留して いた。 MEP は 66〜790, MPP は 52〜120, PAP は $58 \sim 347 \mathrm{ppm}$ であった。 木部にはそれぞれ数 ppm が残 留した。髄では MEP のみが 0.13〜1.08 残留してい た。薬剤を処理した桑株から収穫した桑葉からの農薬は 検出されなかった。この桑葉でカイコを飼育した結果， カイコは正常に発育し営藏した。しかしながら MEP と $\mathrm{MPP}$ 処理株の桑葉で飼育したカイコの桠は藏重におい て若干軽かった。 